\title{
TRANSNATIONAL ORGANIZED CRIMES (TOCS)-CAUSES, EFFECTS AND CHALLENGES: THE PERSPECTIVE OF LATIN AMERICA
}

\author{
Nafiu Ahmed \\ Coventry University, UK \\ Email: ahmedn40@uni.coventry.ac.uk
}

\begin{abstract}
The criminal networks in Latin America are expanding and diversifying their activities. As a result, there is a convergence of threats that were traditionally different to modern-day threats that are explosive and with destabilizing-filled impacts. Criminal violence associated with TOC is the most severe problem facing the nations in Latin America. The increased cases of TOCs in the region have led to insecurity and violence across the region, hence; challenges to residents, public security forces and travelers. The factors leading to TOC in the region have been grouped into suitable geostrategic position, poor governance, corruption, poverty, and also issues of inequality and social mobility. Corruption has greatly facilitated TOC as an organized crime representative bribe, such government officials as police officers and the judges. TOCs impair the social and economic systems in the region, undermining the capacity of the nations to govern, and also creating a non-friendly environment for the travelers due to high incidences of kidnapping. TOC in Latin America has extended beyond its traditional strongholds of Colombia and Mexico; hence there is the need for multinational agencies and governments to cooperate in combating the challenge. However, this paper discusses the causes, effects and challenges of transnational organised crimes (TOCs) from the perspective of Latin America. This paper also glimpses at the security system in Latin American countries and how TOCs affect the security system in this region.
\end{abstract}

Keywords: Transnational Organised Crime. Latin America \& Security and Threat.

\section{Introduction}

Transnational organized crime (TOC) brings forward a serious and growing threat to not only national, but also the international security, and further severe implications for the safety of the public, public health, democratic institutions and also through disruption of the existing economic stability across the world. Organized crime can be described as a social network with individuals who commit illegal activities in a prolonged period with the objective to gain control and biggest economic benefits (Solis and Aravena, 2009). The criminal networks in Latin America are not only expanding, but they are also diversifying their activities leading to the convergence of threats that were traditionally different, and today they are explosive and possess destabilizing impacts. The people of Latin America (Mexico, Central and South America, Cuba, Caribbean, Puerto Rico, and the Dominican Republic) view crime, especially criminal violence as the most significant problems facing their nations today. The violence has been attributed to the high cases of regional cocaine trafficking since the year 2006. Even though the association between cocaine and criminal violence is true, the matter is too complicated in reality than it is portrayed on the outside. Besides, as reported by the United Nations on Drugs and Crime (in Vienna), Latin America is considered the most dangerous region globally regarding homicides (UNODC, 2012). With the increased occurrences of transnational organized crimes in Latin America, there is the need for governments to develop capacity necessary to take control over the national territories and also consolidate democracy through practice of justice. 


\section{Asia Pacific Journal of Advanced Business and Social Studies \\ ISBN (eBook): 9780994365675 I ISSN : 2205-6033 \\ Year: 2017 , Volume: 3, Issue: 2}

\section{TOC in Latin America}

Transnational Organized crime entails criminal activities that are well pre-meditated and threatens peaceful coexistence and human security. Similarly, transnational organized crime leads to a violation of human rights and further undermines the social, economic, cultural and political development of the affected societies (McDermott, 2015). Organized crime is not static, but changes as new and sophisticated crimes emerge and also as ties between criminal networks attain flexibility, complexity and also becomes global. The transnational nature of organized crime implies that criminal networks form relationships across borders through overcoming linguistic and cultural differences in their operations. The growth of transnational organized crime in Latin America has led to a rise in insecurity and violence across the region, thus posing dire challenges to citizens, public forces for security as well as travelers. Besides, migrants who cross the region remain vulnerable as the likelihood of being attacked or trafficked in considerably high. Among the nations that are most susceptible to transnational organized crime in the area include Venezuela, Mexico, Bolivia, Colombia, Guatemala, Honduras, and Peru (McDermott, 2015).

Venezuela is at greatest risk of high rates of organized crime thus pose a significant threat to the security of citizens in the country. The Chavista regime has been noted to crumble as a result of the increased violent crimes as seen by the internal divisions as well as economic problems in the state. Venezuela is the most dangerous nation in South America in terms of crime, whereas Caracas is considered the most dangerous capital in the region. The major challenge facing the country is a lack of a monopoly on control of firearms since many armed collectives, who are a rural rebel group, have proliferated street gangs with increased access to weapons (McDermott, 2015). Besides, Venezuelan prisons have been reported to be the most violent in the world since it acts as centers of activities by criminals who have reached far beyond the walls of the jails. Besides, counterfeiters are on the rise in the region due to the scarcity of dollars despite the control of currency, as individuals and businesses are increasingly seeking foreign currencies thus leading to inflation in Bolivar. Other transnational crimes include corrupt and ineffective police officers, a politicized judiciary, as well as the fact that most of the limited abilities of the law enforcers are directed towards crushing the political opposition rather than fighting crime.

In many states in Mexico, there is the challenge of alliances existing between mafia, local elites and the police. The political aspect of impunity, as well as the incompetence of the government to address the transnational crimes, is also worrying. Besides, Bolivia, a poor, landlocked country is considered the fastest growing market for illegal drugs in the world. There is increased smuggling of marijuana and cocaine which pose high risks due to rising homicides, thus a growing rate of transnational organized crime as well as the development of more complex syndicates of organized crimes (McDermott, 2015). Other crimes in the region include the increased trafficking of drugs (cocaine and heroin)(Hyde, 2014). Honduras, for instance, acts as the center for such crimes as it links Colombian organizations trafficking drugs and the Mexicans who dominate the US market.

As explained by the United Nations on Drugs and Crime in Vienna, the groups involved in the transnational organized crime can be divided into trafficking and territorial groups. Territorial groups i.e. Guatemalan crime families have emphasized their activities in taking control over the geographical region as well as taxing all criminal activities such as drug trafficking involved in the region. The groups display some level of violence which is essential to maintain their control in the region. Trafficking groups (transportistas) on the other side have their focus in flying under the radar as they are involved in transporting contraband goods from one area to the other, and at the same time, pay tribute to territorial groups as required (UNODC, 2012). Trafficking of cocaine is considered the most viable organized crime activity in the Latin America region, even though it is not the only activity. 


\section{Asia Pacific Journal of Advanced Business and Social Studies \\ ISBN (eBook): 9780994365675 | ISSN : 2205-6033 \\ Year: 2017 , Volume: 3, Issue: 2}

Organized crime groups are also involved in dealing with firearms that are either stolen or purchased from corrupt government officials. Besides, military weapons are smuggled in both the north and the south regions of Latin America.

\section{Causes of Transnational Organized Crime in Latin America}

The causes of transnational organized crime in the region can be grouped into suitable geostrategic position, poor governance, corruption, poverty, and also issues of inequality and social mobility. Corruption is considered the most powerful promoter of transnational organized crime where organized crime groups are involved in corrupting certain government officials such as the security forces as well as the judiciary. Organized crime has had high interest in being involved in the political arena in many Latin American countries (McDermott, 2012). As shown by the annual rankings on corruption by the Transparency International, corruption is the greatest driver of such crimes in the region. Similarly, the Non-governmental organization, Transparency International (TI) has been involved in the release of how countries are ranked based on their corruption levels since the year 1995 . Even though the number of nations surveyed as well as the methods applied is changing over time, countries in Latin America have been reported to be the most corrupt, particularly due to involvement in the transnational organized crime.

According to the most recent index by the Transparency International, in 2013, Venezuela and Haiti were the most corrupt nations in Latin America and the Caribbean region. The other nations high on the list are Paraguay, Nicaragua, Honduras and Guyana respectively. Such countries with high rates of corruption are reported to have considerably elevated levels of transnational organized crime. On the other side, countries such as Chile, Uruguay, Barbados and the Bahamas are considered the least corrupt; hence have low reported cases of organized crime. However, as explained by McDermott, it is essential to note that once countries are ranked on the basis of the strength of organized crimes in relation to corruption, there would result in a distinct list. There exists a difference in situations when officials ask for bribes in order to grant permits, secure government contracts, and also facilitate disappearance of speeding tickets; and a situation where the entire police forces in the municipal are on the payroll of the drug cartel, as the case in Mexico(Mc-Dermott, 2012 ). The level of corruption in most Latin American countries is detrimental such as when drug traffickers give money to officials; massive scale funding of political campaigns by illegal gold miners as it happens in Peru; and also the most severe case where Pablo Escobar in Colombia bribed and intimidated the whole Constituent Assembly to illegalize extradition (McDermott, 2012)

Organized crime groups attempt to corrupt state officials so that the latter can turn a blind eye to the illegal activities or be involved in the facilitation of the same(Mc-Dermott, 2012 ). The organized crime groups usually target the police who are the force expected to investigate any illegal activities; with the anti-narcotics being the priority targets for drug traffickers in the region. The drug trafficking activities also target officials (police included) who are responsible for controlling the ports and airports which are potential transit or departure points for the shipment of drugs. Investigations into activities of organized crime are in the hands of either police officers or the office of the attorney general who often fall victims of intimations and or bribery. If the activities of the organized crime groups fail to prevent their cases from being investigated and they end up in jail, they attempt to run their illegal businesses from prison, through bribing of prison officials and wardens. Once convicted, there have been cases of criminals buying themselves presidential pardon, as have been evident in Peru.

As explained by (Solis and Aravena, 2009)), organized crime thrives and prospers as a result of the corruption of the society as well as the State, and the fact that the issue of corruption 


\section{Asia Pacific Journal of Advanced Business and Social Studies \\ ISBN (eBook): 9780994365675 I ISSN : 2205-6033 \\ Year: 2017 , Volume: 3, Issue: 2}

has not been considered a government agenda. Besides, the fight against corruption in Peru remains not a priority as during the era of Alan Garcia's rule, the social problem was not mentioned. Besides, there has existed a close connection between members of organized crime groups and the government, such as the fujimorism, as the members of parliament in fujimorism support the activities of the government. Many syndicates of organized crime have relied on total protection from high ranking political figures, with the highest profile instances if such occurrence being in Columbia. In the year 1994, it was believed that the Cali Cartel paid \$6 million to ensure that Ernesto Samper, who is the present Secretary General of UNASUR, won the presidency. The Latin American nations ranking on the basis of the organized crime's potential to corrupt the state, as well as public sector perception of the group's corruption level places Mexico as the most corrupt nation (McDermott, 2012).

Poverty is another dominant factor which facilitates TOCs in this region. The high occurrence of crime in the region, particularly the trafficking of drugs is associated with high levels of poverty and unemployment. As explained by Arnson and Orson (2011), a high proportion of the crimes are committed by young people. The youth are most affected by high levels of unemployment, hence they tend to live in abject poverty. Therefore, they readily accept to be part of the transnational organized crime as a means to their livelihood. For instance, a country like Puerto Rico has turned out to be a significant transshipment station for illegal drugs smuggled from such nations as Peru and Colombia(Solis \& Aravena, 2009). The drugs are trafficked directly from other source countries into the island, hence they are less costly as compared to other places in the United Sates. Therefore, they attract the street gangs who further buy and deal it to the population, hence increased turf wars and the high rates of homicide in the US. In that light, the move to address social inequality would greatly diminish the high rates of transnational organized crime in the region.

Besides, poverty and absence of opportunities in the society supplies criminal organizations with fresh recruits. Even though there exist no official data indicating the number of young people who work for organized crime cartels, most of the individuals charged with such offences as drug trafficking, violence, rape and murder are the unemployed (Mc-Dermott, 2012). Mc-Dermott further explains that the high rate of youth unemployment in Mexico is a significant factor contributing to TOCs. Mexican officials charged 214 minors who were involved in organized crime in the year 2010, a number that had increased from only eight youths in 2007 unemployed (Mc-Dermott, 2012).

The next factor for the high rates of transnational organized crime in Latin America is the issue of poor governance. There have been institutional vacuums in that the approaches to organized crime in the region, such as in Brazil, has been coupled with failure and inconsistencies (Thoumi, Manaut and Sain, 2010). The activity of organized crime groups in Latin America thrives in the weak and fragile institutions in the region, and not to mention the geographical closeness to drug markets ((Arnson and Orson, 2011). In the case of Latin America, the process of democratization that occurred in the 1980 s and 1990 s resulted in the installation of democratically elected officials, but the government officials have increasingly turned out to be corrupt and incompetent in fighting organized crimes.

The regimes in most Latin American nations fail to comply with the prototype of a free democracy since they are hindered by the problem of dealing with their dictatorial features of the past. The liberal democracies used to be weak states in the earlier days, but with stable governments, but in the modern world, most have been turned into weak states with even more fragile governments (Solis and Aravena, 2009). However, as explained by Solis and Aravena, there is an exception of Chile and Puerto Rico, whereas all the others have certain weaknesses that lead to non-optimal levels of governance. Such governments cannot prevent the proliferation of criminal organizations that turn to violence in attempts to establish 


\section{Asia Pacific Journal of Advanced Business and Social Studies \\ ISBN (eBook): 9780994365675 I ISSN : 2205-6033 \\ Year: 2017 , Volume: 3, Issue: 2}

absolute control over competitors, its members, as well as the illegal market that sells drugs, protection, carry out money laundering and also smuggle humans for sale and also for sex(Solis and Aravena, 2009). As further explained by Bagley, organized crimes are noted to thrive best in the contexts offered by weak states that have poor governance.

Another significant factor facilitating TOCs in Latin America is the geographical positions of the individual countries in the region. El Salvador is vulnerable to TOCs as its geographical location makes it a suitable transit point for drugs as they are being transported from the Andean region to the United States (Miraglia, Ochoa \& Briscoe, 2012). The geo-strategic location of other states such as Mexico and Colombia act as the starting points of the routes of the global business involving cocaine. For instance, the Andean Region, particularly Colombia has connections with Central America, the Caribbean, Mexico, and also North America. Besides, on one side, the African corridor or route links Venezuela, Guyana, Colombia and Brazil; and on the other hand, it connects Guinea, Guinea-Bissau, Togo, and other West African countries for cocaine that is transported to Europe (Hofmann, 2009). As explained by Hofmann, the consumption of Cocaine has significantly risen in Europe and also in Latin America and West Africa, thus the implication that South American drug trafficking cartels have been successful in marketing their goods via the new developed West African transit nations' corridors.

\section{Effects of TOCs in Latin American Nations}

Transnational organized crime has been termed a growing worldwide problem. In Latin America and the Caribbean, organized crime groups have increasingly undermined the capacity of the nations to govern. Therefore, the significant impact of TOCs in Latin American countries is its ability to undermine democratic governance. Organized crime have adopted strategies of the globalized economy, for instance, they are highly flexible, have the potential to adjust to changes in the market, as well as the exploitation of socially weak society segments for their selfish gains (Thoumi, Manaut \& Sain, 2010). As explained by Hyde, the Caribbean and Latin America share the same characteristic of having the highest rates of homicides in the world, thus posing serious social impacts in the various states. Besides, in Latin America, Colombia is the country third affected with crimes of human trafficking and is behind Panama and Venezuela (Bunker \& Sullivan, 2015; Berdal \& Serrano, 2002).

Besides, organized crime gains their operational control to and through politics, hence weakened Latin American nations face severe pressure. Therefore, the recently democratized states such as Mexico face dire impacts emanating from organized crime. Organized crime has the fundamental goal of eroding the democratic governance, a role that is marked by regions of fragile statehood, the non-state actors' move to replace of social policies, the undermining of political structures, the illegal financing of political campaigns and also bribing of political and government officials (Thoumi, Manaut \& Sain, 2010) The strengthening and expansion of transnational organized crime impair the rule of law, with the damaging repercussions of the situation transcending high rates of crime. The transition from the basic trafficking of drugs to organized crime that attempts to control the various territories, as well as the violence linked with the crime groups is the most important phenomenon in the past two decades in Mexico, Caribbean nations and several Central American countries (Calderon, 2015). TOCs not only deteriorates individual liberties and social order, but it also poses an actual threat to the affected state and its democracy since the crime organizations place their focus in displacing and substituting institutions and agencies meant to enforce the law (UNODC, 2012). As the organized crime groups overtake the government and gain control of the state, they extract the rents of society through the threat of violence, or actual violence (Calderon, 2015). The organized crime usually threatens, or even kills the mayors or police chiefs who courageously reject bribes, and the 


\section{Asia Pacific Journal of Advanced Business and Social Studies \\ ISBN (eBook): 9780994365675 I ISSN : 2205-6033 \\ Year: 2017 , Volume: 3, Issue: 2}

act is driven by the Mexican phrase 'ley de plata o plomo', or 'silver or lead law,' which means, take the money or get shot(Calderon, 2015) Therefore, the crime organizations in Mexico employ intimidation or corruption, hence makes the state chronically weak and vulnerable.

The next repercussion emanating from TOCs is the impairment of the social and economic systems in various countries. The high number of drug trafficking organizations (DTOs) that fight over the control or regions and trafficking routes have resulted in a rise in homicides rate as well as other crimes (Robles, Calderon \& Magaloni, 2014). Marginal increases in violence pose negative impacts on labor participation as well as rates of unemployed individuals in the Latin American states (IDMC/NRC, 2010). The fight against organized crime increases the executions between antagonistic criminal organizations, which result in deterioration of order that brings about high rates of robberies, extortion, kidnappings, murder as well as threats that impact the entire population of state involved Robles, Calderón \& Magaloni, 2014). In Mexico for instance, by the year 2011, more than 50,000 drug-trafficking deaths were registered, with the great percentage of the deaths being caused by violence between drug cartels that fight for control of routes and locations suitable for trafficking drugs to the US (the world's largest market) (Robles, Calderón \& Magaloni, 2014; Everett, 2011). As further explained by Everett, most of the drugs such as marijuana, heroin, and methamphetamine found in the United States is controlled by Mexican-based TCOs.

Transnational Organized crime (such as drug-related violence in Mexico) affects the economy of the affected nations. As explained by Robles, Calderón, and Magaloni (2014), illegal drug traffickers in Mexico sometimes behave either as "roving" or "stationary" bandits, and the difference is expected to have dire impacts on economic activities. For instance, El Cartel de Tijuana went through an internal division between two factions, with one led by Teodoro Garcia Simental, a group that encouraged Tijuana kidnappings, while the other faction under Luis Fernando Arellano had strong economic and political links in the city, and focused on drug trafficking and reduced kidnappings since most of the victims of the latter were businessmen(Robles, et al., 2014). The increased kidnappings and torture of individuals in Mexico, Colombia, and El Salvador by organized crime has led to the disruption of the social setting, hence social repercussions such as psychosocial trauma, depression, and also the normalization of violence in the affected communities. Similarly, human smuggling from Mexico to the US has significant impacts on the economy of both nations as the smugglers hinder the legal process of immigration. As explained by Robles, Calderón and Magaloni, a price as high as US\$10,000 is paid to facilitate the smuggling trip from the Mexican south-eastern coast across the border to the US. Besides, Robles, Calderón and Magaloni explain that since about 3 million Latin Americans are illegally smuggled to the US across the south-east border annually, and 90\% of them are assisted by smugglers, the facilitators earn a total income of about 6.6 billion dollars yearly. In Bolivar, (Venezuela) on the other hand, there is scarcity of dollars despite the currency controls, however, counterfeiters continuously enjoy a boom as individuals and businesses continue to seek foreign currency. As a result, there is a 60\% inflation rate in the country (McDermott, 2015).

The cost of crime could best be calculated after estimating the cost of crimes like assault and robbery, homicides, violence, and also containment of the government. as explained in The Huffington Post by Ferreras, the economic impact of violence in Mexico was approximately 2.12 trillion pesos ( $\mathrm{C} \$ 154$ billion) in the year 2015, which was equivalent to about 19 percent of the country's GDP.

Therefore, the transnational organized crime that focuses on such vices as threats of violence or actual violence, murder and kidnappings pose serious economic implications for the victims of such wrongdoings are usually to businesspeople and working population who make control the economy. The war between cartel rivals and the government have forced 


\section{Asia Pacific Journal of Advanced Business and Social Studies \\ ISBN (eBook): 9780994365675 | ISSN : 2205-6033 \\ Year: 2017 , Volume: 3, Issue: 2}

business owners to close their enterprises and move to safer territories. Violence related to drug-trafficking in Mexico has forced approximately 230,000 individuals to leave their homes, particularly in Chihuahua, Tamaulipas, Nuevo Leon, Baja California, Michoacan and Sinaloa, and about half of the people have relocated to the United States (IDMC/NRC, 2010). A significant proportion of the individuals who migrate own businesses, and they continue their businesses from one city to the other along the border between Mexico and the US, such as McAllen, Texas, and Brownville (The Economist , 2012). Besides, in other Latin American states such as El Salvador, the TOC has led to significant economic repercussions, bearing in mind the organized crime first appeared in the country during the civil war (from 1980-1992) (Miraglia, Ochoa \& Briscoe, 2012). As a result of the violence in the country, there were increased deaths $(80,000)$, torture of citizens, missing individuals $(9,000)$ as well as about 1 million homeless and displaced people (Miraglia, Ochoa and Briscoe, 2012). The consequences of the civil war in El Salvador are increasingly felt today, and the drug traffickers have led to factions, corruption, and migration of people, hence a negative impact on the socio-economic situation in the country (Miraglia, Ochoa \& Briscoe, 2012).

\section{TOC and National/Regional Security}

The definition of security has changed over the years, particularly in the post-Cold War world, where a more refined perspective is required, and which should include such 'soft' security aspects as human, social and environmental threats (Swanstrom, 2007). The present state and level of sophistication of Latin American transnational criminal organizations (TCOs) pose a threat to the security of the region (Everett, 2011). Besides, the TOCs threat in Latin America is aggravated by the evolution and associated likelihood of the organized crime to develop connections with the US list of terrorist organizations and also criminal groups of foreign countries. Organized crime presents a threat to regional governments such as Mexico, El Salvador, and Colombia, while other nations such as Honduras and Guatemala are reported to have the highest rates of murder globally (McDermott, 2012).

Over the past decade, TOCs networks have significantly gained importance and influence in the Caribbean and Latin America (Fraser and Novakoff, 2013). The criminal groups in the Latin America not only pose a security threat locally, but also are known to impair national security. As explained by Nai' m (2007), in the current world, the criminal structures are capable of operating globally through connecting remote places in the world as well as in most cosmopolitan towns. Besides, the problem of compromised regional security is severe in 'Northern Tier' nations of El Salvador, Guatemala, Belize, and Honduras where the criminal networks portray increased exploitation of the weak governance structures, corrupt officials, and also thrive in porous borders to traffic drugs, people, weapons, chemicals, and bulk cash (Fraser and Novakoff, 2013). In the four Latin American countries, violent criminal groups as well as other gangs accelerate rates of murder and also impair the security of citizens.

As further observed by the US intelligence community, there is a substantial nexus between terrorism and organized crime. There is an increased likelihood that terrorist organizations will seek funding and logistics from crime and criminal networks. The most suitable Latin American examples showing the connection between terrorism and TOCs are the rebel groups in Colombia like the National Liberation Army (NLA) and the Revolutionary Armed Forces of Colombia (FARC) (Mc-Dermott, 2012). The rebel groups are increasingly involved in extortion and kidnapping. Latin American-based transnational organized crime is beyond doubt strengthening as compared to what it used to be in the past three decades. The organized crime has extended beyond its traditional strongholds of Mexico and Colombia; hence it has become the fundamental threat to regional security in Latin America, and thus a significant threat to the US (Mc-Dermott, 2012). 


\section{Asia Pacific Journal of Advanced Business and Social Studies \\ ISBN (eBook): 9780994365675 | ISSN : 2205-6033 \\ Year: 2017 , Volume: 3, Issue: 2}

\section{Challenges Faced by Governments and Agencies in Fight against TOCs in Latin America}

Organized crime in Latin America would not be such a successful enterprise were it not for the willingness of the government officials and other corporate administrators to engage in organized criminal practices to benefit them. As explained by Everett (2011), highly placed executives of major financial institutions and also government officials in such nations as Argentina and Mexico often cooperate with criminals and cartels as they accept bribes, or else become victims of extortion. As a result, there is increased proliferation of the organized crime since the operations thrive well under impunity.

Lack of a clear understanding of the operation, mechanisms and also driving factors of the TOC is a key challenge facing the governments in the fight against transnational organized crime. The agencies and governments involved in combating TOCs in Latin America have the propensity to take a homogenous view of organized crime in the region. As a result, there is increased interpretation and presentation of the challenge of TOCs as a uniform one (Thoumi, Manaut and Sain, 2010). The agencies fail to fathom that organized crime is a diversified, complex, and multifaceted challenge with different manifestations, has varying forms of activities and dimensions and has distinct determining factors depending on the geographic location. Different crime organizations have varied modes of operation; hence the means put in place to combat each organized crime should be group-specific.

The second challenge interfering with the fight against TOCs is economic dominance of the criminal groups. The wealth and power of the criminal groups further deepens corruption of government officials and also leads to increased intimidation of members of the society, and as a result, the TOC cartels operate with a certain level of impunity (Fraser and Novakoff, 2013). As further explained by Fraser and Novakoff (2013), the total value of the criminal networks from the cocaine trade that is destined for North America exceeds the gross domestic product (GDP) of each nation in Latin America, excluding Brazil. For instance, the Mexican drug lords and smugglers have a considerably high total income per year (about 6.6 billion dollars), hence they can bribe the police and the judges, thus they operate with impunity(Everett, 2011). The bribery emanating from TOCs in the region is about $\$ 1$ trillion whereas trafficking of drugs generates approximately $\$ 750$ billion to $\$ 1$ trillion, pirated and counterfeited goods are estimated to be $\$ 500$ billion while the illicit sale of firearms adds up to $\$ 320$ billion (Everett, 2011). Therefore, the criminal groups often corrupt government institutions through donations and campaign fundings thus form alliances to gain space and control in doing business (Fraser and Novakoff, 2013). There is the need to note that government actions to combat cartel leaders leads to a considerable increase in violence since groups seek to take advantage of the government actions via trying to take control of the regions of the weakened rivals. Besides, there are succession struggles within the affected organizations leading to disintegration into rival group (Fraser and Novakoff, 2013).

There is also a lack of cooperation between governments in the fight against the powerful crime organizations. Since the organized crime have increasingly gained control of broader regions, the governments and agencies should cooperate in combating TOCs. Similarly, there is the need to form partner nation capacity that will keep pace with national, as well as regional campaigns to arrest the leaders of the criminal groups, which will ultimately lead to the dismantling of their criminal networks.

\section{Conclusion}

Transnational organized crime (TOC) pose a serious and growing threat to not only the national but also the international security, and further severe implications for the public safety, public health, democratic governance as well as disruption of the current economic stability across the world. Among the countries that are most vulnerable to TCO in Latin 
America include Venezuela, Mexico, Bolivia, Colombia, Guatemala, Honduras, and Peru. The political aspect of impunity, coupled with the incompetence of the governance institutions to address the transnational crimes is also worrying. The drivers of TCOs in the region can be grouped into suitable geo-strategic position, poor governance, corruption, poverty, and also issues of inequality and social mobility.

As a result of the TCOs, there is a compromise of the democratic governance institutions, economic impacts as the businesspeople tend to migrate from their regions of operation due to fear of kidnapping and threat of violence, and the impairment of the social systems. There is the need for governments and agents to address the challenge of TOCs in order to restore security not only in the region but also in the whole world. Democratic governments should uphold the rule of law and also maintain integrity which is necessary to curb the high rates of corruption. Besides, there is the need to address each organized group as a distinct organization with unique features, driving forces, and manifestations. Lastly, governments and agencies should target and arrest organized crime leaders in order to dismantle the entire criminal organizations. 


\section{References}

i. Arnson, C. \& Orson, E., 2011. Organized Crime in Central America: The Nothern Triangle. s.l.:Latin America Program.

ii. Bagley, B., 2011. Globalization and Transnational Organized Crime: The Russian Mafia In Latin America And The Caribbean. s.l.:Transnational Organized Crime..

iii. Berdal, M. \& Serrano, M., 2002. Transnational organized crime and international security : business as usual?. Boulder, Colorado: Lynne Rienner Publishers.

iv. Bunker, R. \& Sullivan, J., 2015. Criminal Insurgents in Mexico and Latin America: A Small Wars Journal-El Centro Anthology. Bloomington, Indiana: iUniverse.

v. Calderón, F., 2015. Drug Trafficking and Organized Crime: Connected but Different., s.l.: Harvard International Review.

vi. Everett, T., 2011. Transnational Drug Trade and Drug War on the U.S.-Mexico border. Mexican Transnational Criminal Organizations and U.S. Drug Policy, 6(1), pp. 1-7.

vii. $\quad$ Ferreras, J., 2016. Mexico's Drug War Has Hurt The Economy Just Like It Has Hurt People." The Huffington Post Canada. [Online]

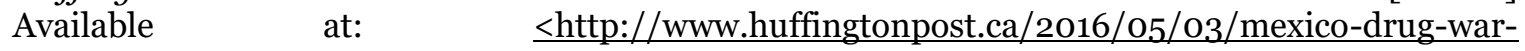
economiccosts n 9825538.html>

viii. Fraser, D. \& Novakoff, R., 2013. Confronting Transnational Organized Crime: Getting It Right to Forestall a New National Security Threat. JFQ, pp. 69(2): 34-38.

ix. Hofmann, K., 2009. The Impact of Organized Crime on Democratic Governance -Focus on Latin America and the Caribbean. FES Briefing Paper, 13(1), pp. 1-9.

x. Hyde, H., 2014. Gangs and Crime in Latin America.. Collingdale: DIANE Publishing.

xi. IDMC/NRC, 2010. Briefing Paper by the Norwegian Refugee Council's Internal Displacement Monitoring Centre on Forced Displacement in Mexicon due to Drug Cartel Violence.. Geneva: IDMC and NRC..

xii. Mc-Dermott, J., 2012 . Transnational Crime 'Abiding Threat' to National Security: US $\begin{array}{lll}\text { Intelligence. Insight Crime. [Online] } & \end{array}$ Available at: $\leq$ http://www.insightcrime.org/news-analysis/transnationalcrime-abiding-threat-tonational-security-us-intelligence $>$.

xiii. $\quad$ McDermott, J., 2014. Latin America Organized Crime: What to Expect in 2015." 2014. Insight Crime. [Online]
[ Available at: $\leq$ http://www.insightcrime.org/news-analysis/organized-crime-what-toexpect-in$\underline{2015>\text {. }}$

xiv. $\quad$ Miraglia, P., Ochoa, R. \& Ivan, B., 2012. Transnational organised crime and fragile states, s.l.: OECD.

xv. Naí m, M., 2007. Illicit: How smugglers, traffickers, and copycats are hijacking the global economy., London: Arrow.

xvi. Robles, G., Calderón, G. \& Beatriz, M., 2014. The Economic Consequences of Drug Trafficking Violence in Mexico. Poverty and Governance., pp. 1-38.

N xvii. Solis, L. \& Aravena, F., 2009. Organized Crime in Latin America and the Caribbean.. Transnational Organized Crime, pp. 11-110. Implications. Global Crime, 8(1), pp. 1-25. 
xix. The Economist, 2012. The ebbing Mexican wave: The world's biggest migration has gone into reverse. [Online]

Available at: $\leq$ http://www.economist.com/news/specialreport/21566781-worlds-biggestmigration-has-gone-reverse-ebbing-mexican-wave $>$

xx. $\quad$ Thoumi, F, et al., 2010. The Impact of Organized Crime on Democratic Governance in Latin, s.l.: Crime Study.

xxi. UNODC , 2012. Transnational Organized Crime in Central America and the Caribbean: A Threat Assessment. Drugs and Crime., pp. 4-82. 